\title{
Karakteristik dan Aktivitas Antioksidan Pedada Beserta Turunannya
}

\author{
Rizki Fadhillah Lubis ${ }^{1,2}$, Gustiarini Rika Putri ${ }^{1}$, Rahmad Syukur Siregar ${ }^{2}$ \\ ${ }^{I}$ Politeknik ATI Padang, Jl. Adinegoro Bungo Pasang, Padang, 25171, Indonesia \\ ${ }^{2}$ Universitas Muhammadiyah Sumatera Utara, Jl. Kapt Muchtar Basri No. 3 Medan, Indonesia
}

\section{ARTICLE INFORMATION}

Received: November 30, 2020

Revised: December 29, 2020

Available online: December 31, 2020

\section{KEYWORDS}

Antioxidant, Pedada

\section{CORRESPONDENCE}

Name: Gustiarini Rika Putri

E-mail: gustiarini_rika@poltekatipdg.ac.id

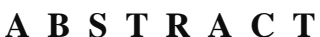

Indonesia is a country with the largest mangrove forests in the world. Indonesia also has various types of mangrove plants, one of which is pedada fruit (Sonneratia caseolaris). Pedada fruit is one type of mangrove whose fruit can be eaten. This fruit has good nutritional content and a source of vitamins A, B and $\mathrm{C}$ that are needed by the body. In addition, pedada fruit also contains phytochemical compounds that are closely related to antioxidant activity. With natural resources and abundant availability and nutrient content, pedada fruit is recommended to be used as processed food in order to increase food diversification. Pedada fruit has been processed into food processed products such as dodol, syrup, flour, ice cream, hard candy flavor, and jam. This study aims to study the characteristics of pedada fruit and its processed products into jam. Pedada fruit and jam have weak antioxidant activity values where the antioxidant activity is $549.91 \mathrm{ppm}$ and $646.25 \mathrm{ppm}$, respectively.

\section{PENDAHULUAN}

Indonesia disebut dengan negara maritim karena hampir 3/4 wilayahnya $\left(5,9\right.$ juta $\left.\mathrm{km}^{2}\right)$ adalah lautan dengan garis pantai mencapai $95.161 \mathrm{~km}$ [1]. Garis pantai yang terdapat di Indonesia sebagian besar ditumbuhi oleh mangrove [2]. Data dari Direktorat Kawasan Konservasi dan Jenis jenis Ikan - Direktorat Jenderal Kelautan Pesisir dan Pulau-pulau Kecil [3], menunjukkan bahwa luas ekosistem mangrove yang terdapat di Indonesia adalah 3.490.000 Ha. Mangrove adalah sebutan umum yang digunakan untuk menggambarkan suatu varietas komunitas pantai tropik yang didominasi oleh beberapa spesies pohon-pohon yang khas atau semak-semak yang mempunyai kemampuan untuk tumbuh dalam perairan asin [4]. Mangrove memiliki jenis-jenis yang beragam, menurut Noor et al [5], jenis mangrove yang terdapat di Indonesia yaitu Avicennia marina, Bruguiera, Rhizophora, Ceriops, Sonneratia alba, Avicennia alba, Soneratia caesolaris dan Nypa fructicans, dan salah satu jenis mangrove yang menghasilkan buah adalah buah pedada (Sonneratia caseolaris). Buah pedada (Sonneratia caseolaris) memiliki berbagai manfaat karena buahnya dapat dimakan [5]. Buah pedada memiliki rasa yang asam dan aroma yang khas yang menjadi daya tarik buah tersebut [6]. Buah pedada tersebut juga memiliki kandungan gizi yang tinggi. Menurut Manalu et al [7], buah segar pedada mengandung kadar lemak 4,82\%, protein 9,21\%, karbohidrat 77, 57\%, kemudian memiliki kandungan vitamin A, B1, B2 dan vitamin C yang berperan membatu metabolisme tubuh.

Selain banyak mengandung vitamin, buah ini juga mengandung senyawa fitokimia. Fitokimia merupakan senyawa yang terdapat di dalam tumbuhan yang biasanya merupakan metabolit sekunder. Senyawa tersebut berfungsi sebagai pertahanan hidup (survival) bagi tumbuhan dan manfaat lainnya yaitu dapat memberikan kesehatan pada tubuh manusia [8]. Menurut Ahmed et al [9], buah pedada memiliki kandungan fitokimia seperti steroid, triterpenoid, dan flavonoid. Komponen fitokimia hasil dari metabolit sekunder pada tumbuhan erat kaitannya dengan senyawa antioksidan alami. Hal tersebut disebabkan karena sebagian besar senyawa antioksidan pada tumbuhan dipicu oleh senyawa senyawa hasil metabolit sekunder [10].

Ketersediaan buah pedada juga sangat melimpah dan dengan biaya murah masyarakat mudah untuk mendapatkannya. Menurut Noor et al [5], Indonesia 
memiliki area hutan mangrove terluas di dunia dengan luas mencapai 3,5 juta hektar. Luas hutan mangrove tersebut melebihi luas hutan Brazil (1,3 juta ha), Nigeria (1,1 juta ha) dan Australia (0,97 juta ha) [11]. Ketersediaan yang melimpah tersebut menjadikan pemanfaatan buah pedada saat ini mulai banyak diperhatikan dan dianjurkan sebagai bahan pangan. Pemanfaatan buah tanaman mangrove yang dapat dikonsumsi bukan sebagai makanan utama, melainkan lebih untuk tujuan penganekaragaman pangan [7].

Pemanfaatan buah pedada sebagai olahan pangan dengan tujuan diversifikasi pangan telah dilakukan. Diantaranya buah pedada telah diolah menjadi sirup [12], dodol [13], ice cream [14], olahan tepung [15] dan penambah flavor dalam pembuatan hard candy [16]. Selain produk tersebut buah pedada juga diolah menjadi selai [12], [17].

Menurut Javanmard dan Endan [18], selai merupakan makanan yang dapat dibuat dari buah-buahan yang berasa asam. Selai dapat dibuat dari proses pemanasan campuran bubur buah dan gula. Selai yang dibuat dari buah pedada sangat jarang terdapat di pasaran.

Menurut Mahammad et al. (2010) dalam Manalu [12], buah merupakan sumber vitamin $\mathrm{C}$, asam folat, dan serat, namun pengolahan pada buah dapat mempengaruhi kandungan gizi yang terdapat di dalamnya, begitu juga dengan pengolahan buah pedada menjadi selai. Kandungan vitamin pada buah pedada saat diolah menjadi selai diduga akan mengalami perubahan dari segi jumlahnya.

Penelitian ini bertujuan memanfaatkan buah pedada menjadi produk olahan selai dalam upaya meningkatkan penganekaragaman pangan. Mempelajari retensi kandungan vitamin selama pengolahan dan memberi informasi aktivitas antioksidan pada buah pedada dan produk olahannya.

\section{METODOLOGI}

\section{Bahan dan Alat}

Bahan yang digunakan pada penelitian ini terdiri dari bahan utama yaitu buah pedada (Sonneratia caseolaris) yang didapat di Desa Rugemuh Kecamatan Pantai Labu Kabupaten Deli Serdang Sumatera Utara, bahan untuk pembuatan selai pedada yaitu gula dan air, dan bahan

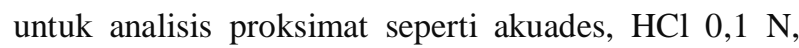
$\mathrm{H}_{2} \mathrm{SO}_{4}, \mathrm{H}_{3} \mathrm{BO}_{3} 3 \%$, NaOH, dan pelarut heksana. Bahan yang digunakan untuk analisis vitamin adalah $\mathrm{KOH}$, asam askorbat, etanol, akuabides, acetonitril, $\mathrm{Al}_{2} \mathrm{O}_{2}$, asam asetat $2 \%$, metanol, larutan dye, dan asam oksalat. Alat-alat yang digunakan pada penelitian ini adalah cawan porselen, desikator, oven, gegep, tabung Kjeldahl, timbangan analitik, alat pemanas, erlenmeyer, kertas saring, aluminium foil, selongsong lemak, tabung soxhlet, pemanas listrik, corong bucher, mortar, labu ukur, Ultrasonic water bath, HPLC, pipet volumetri, dan sentrifus.

\section{Metode Penelitian}

Penelitian terdiri dari lima tahap yaitu pembuatan selai pedada, uji kesukaan selai pedada, analisis proksimat buah dan selai pedada menggunakan AOAC [19] dimana kadar air dan abu, kadar lemak dengan metode soxhlet, protein dengan metode kjeldahl serta kadar karbohidrat dengan metode by difference, analisis kandungan vitamin C pada buah dan selai pedada menggunakan dengan metode titrasi, uji aktivitas antioksidan buah dan selai pedada dengan metode DPPH [20].

\section{Pembuatan Selai Pedada}

Pembuatan selai pedada dilakukan berdasarkan pembuatan selai buah menurut Manalu et al [7] yang dimodifikasi. Pembuatan selai pedada diawali dengan dilakukan preparasi terhadap buah pedada yang digunakan. Buah tersebut dipisahkan antara daging serta biji, kelopak, dan kulit. Hasil preparasi berupa daging dan biji dicampurkan dengan air secukupnya, kemudian dihasluskan dengan blender. Campuran yang telah halus disaring dengan saringan dan diperoleh hasil saringan berupa bubur buah dan ampas. Bubur buah hasil saringan tersebut digunakan pada pembuatan selai pedada dan ampasnya dibuang.

Campuran bubur buah dan gula dipanaskan dengan suhu $105^{\circ} \mathrm{C}$ selama $\pm 1,5$ jam. Variasi campuran antara buah dan gula sebagai berikut;

Perbandingan Buah Pedada : Gula

$\mathrm{A}=45: 55$

$\mathrm{B}=50: 50$

$\mathrm{C}=55: 45$

$\mathrm{D}=60: 40$

Campuran tersebut diaduk terus menerus hingga menyusut (airnya menguap) dan mengental. Campuran yang telah menjadi selai pedada setelah proses pemanasan selesai langsung dipindahkan ke wadah steril. Pemindahan langsung selai bertujuan agar selai tidak mengeras.

\section{HASIL DAN PEMBAHASAN}

\section{Uji Organoleptik}

Uji organoleptik dilakukan untuk mengetahui tingkat penerimaan panelis terhadap selai pedada yang dihasilkan. Uji organoleptik dilakukan oleh 20 orang panelis dengan parameter meliputi warna, aroma, rasa dan tekstur. 


\section{Warna}

Dari hasil organoleptik yang dilakukan panelis terhadap 4 jenis sampel untuk tingkat kesukaan pada segi warna, didapat hasil persentase yang tertera pada gambar 1 berikut ini:

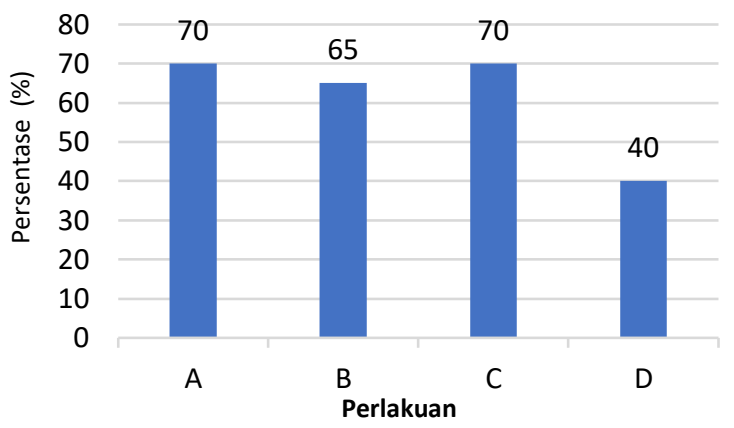

Gambar 1. Nilai Persentase Tingkat Kesukaan Terhadap Warna

Berdasarkan data pada grafik di atas, dapat dilihat bahwa warna kecokelatan pada selai relatif dapat diterima oleh panelis, hal ini terlihat dari tingkat penerimaan panelis terhadap warna pada selai yang dihasilkan adalah 40$70 \%$. Warna produk makanan merupakan daya tarik utama sebelum konsumen mengenal dan menyukai sifatsifat lainnya. Dengan melihat warna, konsumen telah dapat menilai mutu bahan pangan dengan cepat dan mudah.

\section{Aroma}

Dari hasil organoleptik yang dilakukan panelis terhadap 4 jenis sampel untuk tingkat kesukaan pada segi aroma, didapat hasil persentase yang tertera pada gambar 2 berikut ini:

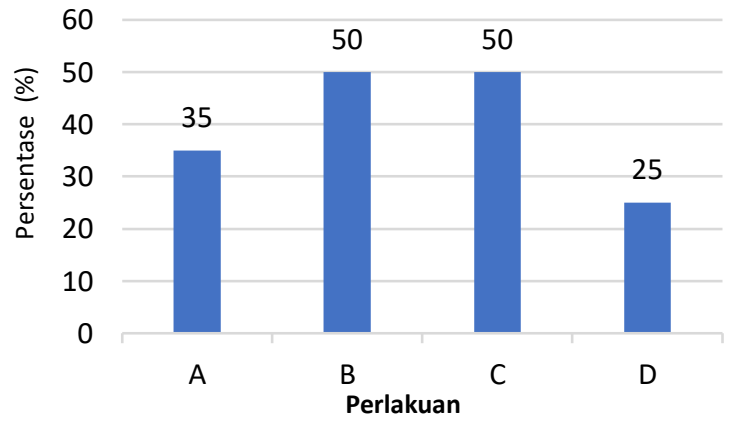

Gambar 2. Nilai Persentase Tingkat Kesukaan Terhadap Aroma

Menurut Winarno [21], bau makanan banyak menentukan kelezatan makanan serta citarasa bahan pangan itu sendiri. Hal yang mempengaruhi citarasa bahan pangan adalah terdiri dari tiga komponen yaitu bau, rasa, dan rangsangan mulut. Berdasarkan data pada tabel, dapat dilihat bahwa aroma pada selai pedada yang dihasilkan relatif dapat diterima oleh panelis, hal ini terlihat dari tingkat penerimaan panelis terhadap aroma pada selai pedada yang dihasilkan berkisar $25-50 \%$.

Aroma selai yang dihasilkan berasal dari buah pedada yang digunakan. Selain itu, aroma selai pedada juga diduga dipengaruhi oleh reaksi Maillard yang terjadi dalam proses pengolahan selai, dimana protein akan mengalami reaksi Maillard akibat bereaksi dengan gula pereduksi yang terdapat dalam bahan. Menurut deMan [22] saat reaksi Maillard terjadi disamping mengakibatkan perubahan warna, bahan juga akan mengalami perubahan rasa dan aroma.

\section{Rasa}

Dari hasil organoleptik yang dilakukan panelis terhadap 4 jenis sampel untuk tingkat kesukaan pada segi rasa, didapat hasil persentase yang tertera pada gambar 3 berikut ini:

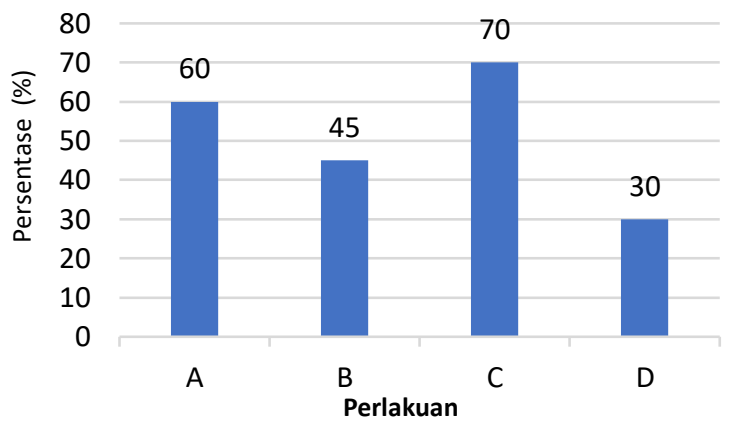

Gambar 3. Nilai Persentase Tingkat Kesukaan Terhadap Rasa

Menurut Winarno [21], rasa lebih melibatkan panca indera lidah. Penginderaan cecapan dapat dibagi menjadi empat cecapan utama yaitu asin, asam, manis dan pahit. Rasa merupakan faktor yang sangat penting dalam menentukan penerimaan atau penolakan panelis terhadap bahan pangan. Berdasarkan data pada tabel, dapat dilihat bahwa rasa selai yang dihasilkan pada perlakuan A dan $\mathrm{C}$ relatif diterima sedangkan perlakuan $\mathrm{B}$ dan $\mathrm{D}$ tidak diterima oleh panelis yang mana tingkat penerimaan panelis terhadap rasa pada selai pedada yang dihasilkan berkisar $30-70 \%$.

\section{Tekstur}

Dari hasil organoleptik yang dilakukan panelis terhadap 4 jenis sampel untuk tingkat kesukaan pada segi tekstur, didapat hasil persentase yang tertera pada gambar 4 .

Penginderaan tentang tekstur biasanya berasal dari sentuhan yang dapat ditangkap oleh seluruh permukaan kulit (ujung jari tangan). Rangsangan sentuhan dapat dari bermacam-macam rangsangan mekanik, fisik dan kimiawi. Dari rangsangan-rangsangan itu dihasilkan kesan rasa rabaan. Kesan itulah yang dapat menggambarkan tekstur suatu produk [23]. 


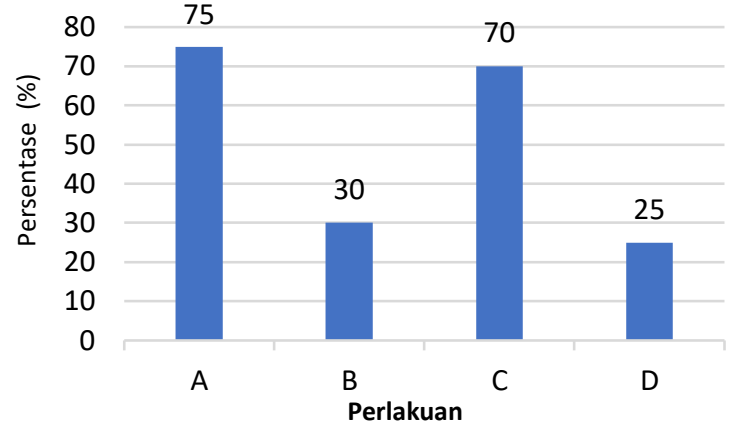

Gambar 4. Nilai Persentase Tingkat Kesukaan Terhadap Tekstur

Berdasarkan data pada tabel, dapat dilihat bahwa tekstur pada selai yang dihasilkan relatif dapat diterima oleh panelis, hal ini terlihat dari tingkat penerimaan panelis terhadap tekstur pada selai padada yang dihasilkan berkisar $25-75 \%$.

Gambar grafik penilaian organoleptik selai pedada dengan perbandingan gula secara keseluruhan ditampilkan pada Gambar 5.

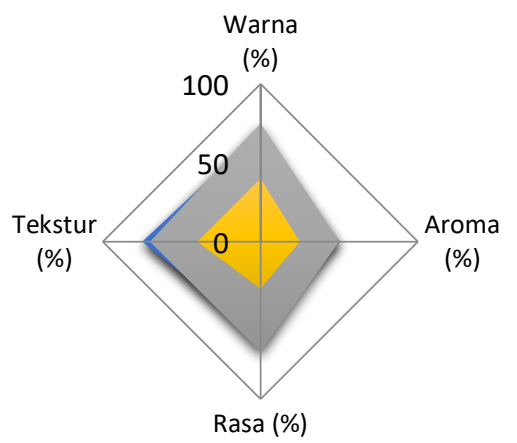

- Perlakuan A

- Perlakuan B

- Perlakuan C

- Perlakuan D

Berdasarkan grafik di atas, disimpulkan bahwa penerimaan panelis yang menonjol terhadap selai pedada dengan perbandingan buah dan gula terdapat pada perlakuan $\mathrm{C}$.

\section{Kandungan Proksimat dan Vitamin C}

Analisis terhadap kandungan proksimat selai pedada dilakukan pada produk dengan nilai organoleptik tertinggi yaitu perlakuan $\mathrm{C}$ dapat dilihat pada tabel 1 .

Tabel 1. Kandungan Proksimat Buah dan Selai Pedada

\begin{tabular}{lrr}
\hline Komponen & Buah $\mathbf{( \% )}$ & \multicolumn{1}{c}{ Selai $(\boldsymbol{\%})$} \\
\hline Kadar air & $81.48 \pm 0.02$ & $10.80 \pm 0.04$ \\
Kadar abu & $1.12 \pm 0.25$ & $1.03 \pm 0.004$ \\
Kadar lemak & $7.86 \pm 1.61$ & $3.25 \pm 0.07$ \\
Kadar protein & $2.69 \pm 0.24$ & $1.41 \pm 0.07$ \\
Kadar karbohidrat & $78.88 \pm 0.38$ & $83.51 \pm 1.98$ \\
\hline
\end{tabular}

Kandungan proksimat buah pedada dan produknya dapat dilihat pada Tabel 1 bahwa terjadi penurunan pada selai pedada terhadap kadar air, kadar abu, kadar lemak dan protein dimana hal ini terjadi akibat adanya pemanasan pada proses pembuatan selai. Kadar air dan kadar abu mengalami penurunan berturut-turut sebesar $86.74 \%$ dan 8.03\% sedangkan kadar lemak dan kadar protein mengalami penurunan berturut-turut sebesar $58.65 \%$ dan 47.58\%. Sementara kandungan karbohidrat meningkat dari $78.88 \%$ menjadi $83.51 \%$.

\section{Kandungan Vitamin C dan dan Betakaroten}

Kandungan vitamin $\mathrm{C}$ dan betakaroten pada buah dan selai pedada dapat dilihat pada Tabel 2. Pada tabel terlihat penurunan vitamin $\mathrm{C}$ dan betakaroten selai pedada dibanding buah segarnya. Penurunan kandungan vitamin $\mathrm{C}$ dan betakaroten selai pedada berturut-turut adalah sebesar $23.26 \%$ dan $57.70 \%$. Penurunan tersebut diduga karena pemanasan. Proses pembuatan selai pedada dilakukan pemanasan pada saat pencampuran bubur buah dengan gula selama 1.5 jam.

Tabel 2. Kandungan Vitamin C dan Betakaroten Buah dan Selai Pedada

\begin{tabular}{lcc}
\hline Komponen & $\begin{array}{c}\text { Buah Pedada } \\
(\mathbf{m g} / \mathbf{1 0 0} \mathbf{g})\end{array}$ & $\begin{array}{c}\text { Selai Pedada } \\
(\mathbf{m g} / \mathbf{1 0 0} \mathbf{g})\end{array}$ \\
\hline Vitamin C & $251.16 \pm 12.11$ & $192.73 \pm 17.15$ \\
Betakaroten & $4.87 \pm 0.31$ & $2.06 \pm 0.13$ \\
\hline
\end{tabular}

Betakaroten adalah bagian dari karotenoid yang merupakan prekusor vitamin A. Menurut Winarno [21], Vitamin A pada umumnya stabil terhadap panas, asam dan alkali. Hanya saja mempunyai sifat yang sangat teroksidasi oleh udara dan akan rusak bila dipanaskan pada suhu tinggi bersama udara, sinar dan lemak yang sudah tengik. Penurunan vitamin $\mathrm{C}$ juga disebabkan adanya proses pemanasan saat pengolahan. Menurut Begum et al. (2009), kandungan vitamin $\mathrm{C}$ buah jeruk dapat rusak akibat panas, air, udara, cahaya, dan penyimpanan.

\section{Aktivitas Antioksidan}

Pengukuran aktivitas antioksidan dilakukan dengan metode DPPH dengan megukur penurunan serapan larutan DPPH pada panjang gelombang $517 \mathrm{~nm}$. Pada tabel 3 dapat dilihat bahwa aktivitas antioksidan selai pedada mengalami penurunan dibanding dengan buah segarnya, dimana penurunan terjadi sebesar $14.92 \%$. Aktivitas antioksidan buah pedada dan selai pedada berturut-turut adalah $549.91 \mathrm{ppm}$ dan $646.25 \mathrm{ppm}$ dimana angka tersebut menunjukkan aktivitas yang lemah, dimana nilai $\mathrm{IC}_{50}$ lebih dari 200 ppm dinilai lemah.

Tabel 3. Aktivitas Antioksidan Buah dan Selai Pedada

\begin{tabular}{lc}
\hline Komponen & $\begin{array}{c}\text { Aktivitas Antioksidan } \\
\text { IC50 }\end{array}$ \\
& $549 m)$ \\
\hline Buah Pedada & $646.91 \pm 10.76$ \\
Selai Pedada & 618.16 \\
\hline
\end{tabular}


Penurunan aktivitas antioksidan selai pedada jika dibanding dengan buah segarnya berbanding lurus dengan penurunan kandungan vitamin $\mathrm{C}$ dan betakaroten. Hal ini diduga vitamin $\mathrm{C}$ dan betakaroten merupakan sumber antioksidan pada buah pedada. Menurut Lung dan Destiani [24], vitamin A, vitamin C dan vitamin $\mathrm{E}$ merupakan senyawa antioksidan alami yang sering digunakan sebagai senyawa pembanding dan vitamin $\mathrm{C}$ mempunyai aktivitas antioksidan yang paling kuat.

\section{KESIMPULAN}

Berdasarkan penelitian yang telah dilakukan dapat diambil kesimpulan yaitu, perbandingan buah pedada dan gula pada pembuatan selai pedada yang terbaik didapat pada Perlakuan $\mathrm{C}$ dengan perbandingan buah dan gula 55:45. Buah dan selai pedada memiliki nilai aktivitas antioksidan yang lemah dimana aktivitas antioksidan berturut-turut sebesar $549.91 \mathrm{ppm}$ dan $646.25 \mathrm{ppm}$.

Saran yang diberikan untuk penelitian selanjutnya perlu dilakukan penelitian lanjutan dengan metode lain seperti pengujian aktivitas antioksidan secara in vivo dan toksisitas pada pedada dan olahannya.

\section{ACKNOWLEDGEMENT}

Terimakasih penulis ucapkan kepada Universitas Muhammadiyah Sumatera Utara yang telah mendanai penelitian ini melalui Lembaga Penelitian dan Pengabdian kepada Masyarakat dengan Skema Penelitian Dosen Pemula Tahun Anggaran 2017/2018.

\section{DAFTAR PUSTAKA}

[1] Lasabuda, Ridwan. "Pembangunan Wilayah Pesisir dan Lautan dalam Perspektif Negara Kepulauan Republik Indonesia”. J. Ilmiah Platax, Volume 1, Januari 2013, Pages 92-101.

[2] Ghazali, I. "Pemanfaatan Mangrove Berbasis Kearifan Lokal Di Pantai Timur Surabaya". Thesis, Institut Pertanian Bogor, Bogor, 2015.

[3] Direktorat Jenderal Kelautan Pesisir dan Pulaupulau Kecil. "Kondisi Mangrove di Indonesia". Internet: https://kkp.go.id/djprl/p4k/page/4284kondisi-mangrove-di-indonesia. Oct. 25, 2020.

[4] Nybakken. Biologi Laut: Suatu Pendekatan Ekologis. Terjemahan. Jakarta: PT. Gramedia Pustaka Utama, 1993.

[5] Noor YN, Khazali M, Suryadiputra INN. Panduan Pengenalan Mangrove di Indonesia. Bogor: PHKA/WI-IP, 2006.
[6] Santoso, N., Kusmana, C., Sudarma, D., \& Sukmadi, R. "Ecological Aspect of Pidada (Soneratia caseolaris Linn. Engler, 1987) at Muara Angke, Jakarta". Jurnal Manajemen Hutan Tropika, Volume 13, 2007, Pages 131-139.

[7] Manalu, R.D.E., Ella. S., Fifi R., Nia K. "Kandungan Zat Gizi Makro dan Vitamin Produk Buah Pedada (Sonneratia caseolaris)". J. Penelitian Gizi dan Makanan, Volume 36, Desember 2013, Pages 135-140.

[8] Hasler CM. "Functional Foods: Their Role In Disease Prevention And Health Promotion". J. Food Tech. Volume 52, 1998, Pages 63-70.

[9] Ahmed R, Moushumi SJ, Ahmed H, Ali M, Haq WM, Jahan R, Rahmatullah M. "Serum Glucose and Lipid Profiles In Rats Following Administration of Sonneratia caseolaris (L.) Engl. (Sonneratiaceae) Leaf Powder In Diet". J. Advances in Natural and Applied Sciences. Volume 4, 2010, Pages 171-173.

[10] Kusyana, D.Y. "Eksplorasi Potensi Bahan Aktif Berkhasiat Antioksidan Pada Daun dan Buah Mangrove Jenis Sonneratia alba (JE Smith, 1816)". Skripsi, Institut Pertanian Bogor, Bogor, 2014.

[11] Spalding, M.D., F. Blasco \& C.D. Field editor. 1996. World Mangrove Atlas. Okinawa: International Society for Mangrove Ecosystems. 1996.

[12] Manalu, R.D.E. "Kadar Beberapa Vitamin Pada Buah pedada (Sonneratia caseolaris) dan Hasil Olahannya". Skripsi, Institut Pertanian Bogor, Bogor, 2011.

[13] Nurwati. "Dodol Mangrove Kaya Vitamin C". PKMK, Institut Pertanian Bogor, Bogor, 2010.

[14] Apriliani, D. "Pengaruh Penggunaan Puree Buah Mangrove (Sonneratia caseolaris) Dan Jumlah Gula Terhadap Sifat Organoleptik Es Krim”. J. Boga, Volume 4, Maret 2015, Pages 116-125.

[15] Jariyah dan Nurismanto R. "Penerapan Teknologi Pengolahan Tepung Buah Mangrove Jenis Padada (Sonneratia caseolaris) Pada Kelompok Tani Mangrove Di Wonorejo Timur Surabaya". J. Rekapangan, Volume 11, Desember 2016, Pages 15.

[16] Nurwati. "Formulasi Hard Candy Dengan Penambahan Ekstrak Buah Pedada (Sonneratia caseolaris) Sebagai Flavor”. Skripsi. Institut Pertanian Bogor, Bogor, 2011.

[17] Setiawan, E, Raswen E dan Netti H. 2016. "Pemanfaatan Buah Pedada (Sonneratia caseolaris) Dalam Pembuatan Selai". Jurnal Online Mahasiswa Faperta, Volume 3, Februari 2016, Pages 1-14. 
[18] Javanmard M, Endan J. 2010. "A Survey of Rheological Properties of Fruit Jams". International Journal of Chemical Engineering and Applications. Volume 1, 2010, Pages 31-37.

[19] Association of Official Analytical Chemist. Official Methods of Analysis of the Association of Analytical Chemist. Virginia USA: Association of Official Analytical Chemist Inc. Arlington, 2005.

[20] Huang, Y.C., Y.H. Chang dan Y.Y. Shao. "Effects of Genotype and Treatment on The Antioxidant Activity of Sweet Potato in Taiwan". J. Food Chemistry, Volume 98, 2005, Pages 529-538.

[21] Winarno, FG. Kimia Pangan dan Gizi. Bogor: MBrioo Press, 2008.

[22] deMan, John M. Principles of Food Chemistry. Penerjemah, Kosasih Padmawinata. Bandung: ITB Press, 1997.

[23] Soekarto, S. Penilaian Organoleptik (untuk Industri Pangan dan Hasil Pertanian). Jakarta: Bharata Karya Aksara, 1985.

[24] Lung, J. K.S.L dan Destiani, D.K. 2017. "Uji Aktivitas Antioksidan Vitamin A, C, E dengan metode DPPH". J. Farmaka, Volume 15, 2017, Pages 53-62. 